\title{
New Zealand Industrial Relations and the International Labour Organisation: Resolving Contradictions Implicit in Freedom Of Association
}

\author{
Tonia Novitz * :
}

The International Labour Organisation (ILO) has long been committed to the promotion of "freedom of association" as "one of the primary safeguards of peace and social justice". Since 1952, the ILO Committee on Freedom of Association (CFA) has considered complaints relating to freedom of association and reviewed domestic legislation. In doing so, the CFA has attempted to establish a set of guidelines for state conduct, but this article suggests that the Committee's efforts have been hindered by contradictions inherent in the principle of "freedom of association".

Individual freedom of choice is often said to be implicit in the very notion of a "freedom". If freedom of association is to be protected, so must an individual worker's freedom to opt out of trade union membership, or an individual employer's freedom to refuse to enter into an agreement with a trade union. However, freedom of association also requires recognition of "association" and collective action, which in the context of labour relations is of particular importance. Trade unions are founded upon the premise that the power imbalance inherent in the individual employment contract can be overcome only by the collective negotiation of terms and conditions of employment. Without the opportunity to participate in collective bargaining, trade unions and other worker associations become irrelevant. It is therefore argued that the principle of freedom to associate entails promotion of collective bargaining. The key question is how far freedom of choice should be limited in the promotion of collective bargaining.

This paper examines how this dichotomy is reflected in the jurisprudence developed by the ILO Committee on Freedom of Association. The Committee's development of a duty to bargain in good faith seems to stem from recognition of the importance of collective bargaining. However, certain cases which criticise government intervention in industrial relations suggest that the CFA is reluctant to endorse considerable restrictions upon an individual's freedom of choice even where these restrictions may promote collective bargaining.

Over the past decade, the CFA has made a number of recommendations in cases relating to New Zealand labour legislation. These also reflect the conflict between promotion of collective bargaining and recognition of individual freedom of choice. Most recently, the Employment Contracts Act 1991 (ECA) was found to be in violation of ILO principles, to the

* Barrister and Solicitor of the High Court of New Zealand, Lecturer in Law at the University of Bristol. The writer would like to thank R. du Plessis, P. Syrpis and L. Tortell for their comments and assistance. 
extent that the Act (which promoted freedom of choice) diminished collective bargaining. This suggests that, ultimately, it is appropriate to give priority to the protection of collective bargaining and at least impose a duty to bargain in good faith.

In its final report, the CFA noted that New Zealand courts had interpreted the ECA in a manner which allowed trade unions access to the workplace and prevented employees from bypassing trade union representatives, but added that there was still no duty to bargain in good faith and without such an obligation collective bargaining had been progressively undermined. The CFA requested that it be kept informed of the judgments of the New Zealand courts, perhaps in the hope that the judiciary might ensure compliance with ILO standards. However, despite recent developments in New Zealand case law, it appears that the judiciary are reluctant to assume this role. If New Zealand is to comply with ILO standards, it seems that legislative reform will be necessary.

\section{Freedom of association: the code of conduct developed by the ILO}

The International Labour Organisation (ILO) is the only tripartite international organisation and consists of government, employer and employee representatives. The Organisation emerged as a result of negotiations at Versailles following the First World War and now has status as a United Nations agency, concerned exclusively with the promotion of international labour standards.

Freedom to associate formed the basis of the first constitution of the $\mathrm{LO}$, contained in the 1919 Treaty of Versailles. In later years, the Declaration of Philadelphia of 1944 reiterated that freedom of association was "essential to sustained progress". The Declaration was incorporated into the ILO Constitution and followed by numerous ILO Conventions and Recommendations concerning freedom of association; the most notable being Conventions No. 87 and 98 .

Government reports upon compliance with Conventions and Recommendations are monitored by the ILO Committee of Experts, which also periodically produces a General Survey on the issue of freedom of association. Moreover in 1950, by agreement with the United Nations, the ILO established the present procedures for examining complaints relating to violations of freedom of association. These are usually heard by the ILO Committee on Freedom of Association (CFA), ${ }^{1}$ although occasionally certain cases will be referred to the Fact-Finding and Conciliation Commission on Freedom of Association. It is possible for the CFA to supplement the information available to them by arranging for a Direct Contacts Mission to visit the state in question. Over the years the CFA has produced a Digest of Decisions, which provides member states with a code of conduct, relating to freedom of association. The most recent fourth edition of the Digest was published in 1996.

1 A tripartite body, consisting of ten members. These are three government representatives, three employer representatives and three worker representatives, as well as an independent chairperson. 
The CFA faces the difficulty that the term "freedom of association" is both general and ambiguous (von Prondzynski, F., 1987: 27). It is possible to identify two common (but starkly opposed) approaches to the interpretation of this principle. Upon one approach, freedom of association is merely a natural extension of individual liberty and the continued protection of personal choice is fundamental to its survival. The opposite view is that, within the context of industrial relations, the function of freedom of association is to redress the power imbalance typical of the relationship between employer and employee. Freedom of association therefore requires promotion of collective bargaining.

Firstly, freedom of association can be regarded as safeguarding individual civil liberty. Individuals should be free to join organisations and to act in association, in so far as they do not cause harm to others. (See Mill, J.S. in his essay On Liberty, p.138). Freedom of association was initially claimed for the protection of groups created for religious, scientific and charitable purposes (Jenks, C.W., 1957: 14). Gradually, this protection was extended to other spheres, one of these being the industrial sphere.

In the very simplest terms, the principle may be reduced to an individual's right to do collectively what one is entitled to do individually (Leader, S., 1992). Accordingly, individual choice has been recognised as an essential aspect of freedom of association. This approach has been adopted wholeheartedly by the European Court and Commission of Human Rights, who have endorsed a negative right of association, that is, a right not to join a trade union or a right not to enter into collective bargaining. ${ }^{2}$ The ILO seems more hesitant to endorse a freedom to disassociate, but seems to recognise the importance of individual choice in the statement that "workers and employers should in practice be able to form and join organisations of their own choosing in full freedom". (See ILO, 1996, Digest, para.274) and Article 2 of ILO Convention 87, 1948).

It has long been argued that the individualistic conception of freedom of association should be modified in the industrial sphere. (See, for example, Jenks, C.W., 1957: 63). The reason given is that, in the context of labour relations, freedom to associate has a particular purpose, over and above an individual desire to meet, worship or study with others. That purpose is to redress long-recognised inequalities of bargaining power between employer and employee, i.e., to promote the ostensible aim of the ILO, namely "social justice" (Preamble to Part XIII of the Treaty of Versailles, 1919).

Those who own capital, or control the means of production, usually are privileged relative to those dependent upon working for a living. This privilege may take the form of greater access to information, greater mobility, greater flexibility in the deployment of resources, control over the media, superior status and greater influence in society at large. In recent years, increasing unemployment and a decline in the availability of full-time or permanent work has exacerbated this power imbalance. Moreover, as Lord Wedderburn recently reiterated, "the very essence of the employment relationship is subordination, the very weakness of the worker" (Lord Wedderburn, 1994: 44). The result is that, in the absence of

2 See, for example, Young, James and Webster $v$ UK and Sigurjonsson $v$ Iceland. See as to the response of the European Commission of Human Rights, Gustafsson v Sweden. 
collective bargaining, an individual employee has little freedom to bargain over terms and conditions of employment. Accordingly, the ILO has recognised that, at least in the industrial sphere, the ability to form and join organisations for the purposes of collective bargaining is also implicit in protection of freedom of association.

Two aspects of CFA jurisprudence reflect the ILO's struggle to reconcile freedom of choice with promotion of collective bargaining. The first concerns the role of government in industrial relations. The second, developed by the CFA over the past 20 years, is the duty to bargain in good faith.

\section{(a) the role of government in industrial relations}

If collective bargaining is purely voluntary, then employers must be given a choice as to whether they wish to enter into collective bargaining. As employees are more likely to benefit from collective bargaining than their employers, one must examine how one might provide employers with an incentive to enter into an agreement with a trade union.

Industrial action might provide one such incentive. Accordingly, although there is no constitutional provision for a right to strike and no mention of such a right in Conventions 87 and 98, the CFA endorses a wide-ranging right to strike (ILO, 1985, Digest, para.362; ILO, 1996, Digest, para.474). For example, strikes may be called in an attempt to persuade employers to recognise the trade union for the purposes of collective bargaining (ILO, 1996, Digest, paras. 487 and 488). However, the success of a strike will depend upon the availability of alternative labour and in the vast majority of OECD countries, which now experience widespread structural unemployment, strikes are less effective than they might at first appear. ${ }^{3}$ Moreover, industrial action is ultimately disruptive and harmful to the parties concerned (ILO Committee of Experts, 1994, para.137).

Another method by which to overcome employers' reluctance to enter into collective bargaining, is for government to set up a structure in which employers are legally obliged to participate. Initially, in 1931, the ILO was hostile to the notion of government interference in industrial relations (International Labour Office, 1931: p.240). Now Articles 3 and 4 of Convention 98, 1949, stress that governments may need to take measures appropriate to national conditions, "to encourage and promote the full development and utilisation of machinery for voluntary negotiation between employers or employers' organisations and workers' organisations, with a view to the regulation of terms and conditions of employment by means of collective agreements". Also, the Committee on Freedom of Association has stated subsequently that governments have an obligation to ensure that the ability to bargain collectively is "fully established and respected in law and in fact" (ILO, 1985, Digest, para.654; Article 4, Convention 98).

See ILO (1994) World Labour Report, Geneva, pp.13-15. The average unemployment in OECD countries is approximately 8.5 percent. ILO, Report of the Director-General(1994), p. 89. 
Nevertheless, the CFA has also said that governments must be careful not to impinge upon workers' (or employers') freedom of choice. For example, the Committee has recognised that it may be desirable "to promote a strong trade union movement by avoiding the defects resulting from an undue multiplicity of small and competing trade unions, whose independence may be endangered by the weakness"; but will not allow governments to impose unification by legislation (ILO, 1985, Digest, para.224; ILO, 1996, Digest, para.271; Creighton, B., 1993: 119). Even where workers request unification of trade unions, this should not be sanctioned by legal texts, "the existence of which might suggest that the unified trade union movement is merely the result of legislation and not the workers' choice" (ILO, 1985, Digest, para.232; ILO, 1996, Digest, para.288). This reluctance is also evident in a case concerning compulsory trade union membership in New Zealand (1986, 244th Report of the Committee on Freedom of Association, Case No.1334, New Zealand).

\section{(b) the duty to bargain in good faith}

Despite these restrictions upon state intervention in labour relations, the Committee on Freedom of Association has suggested that the state would be justified in imposing upon employers and trade unions an obligation to bargain in good faith. The CFA has recognised the dangers implicit in allowing one party, usually the employer, to adopt "an uncompromising attitude towards the demands of the other party" in a collective bargaining situation. Accordingly, the CFA has stressed "the importance which the Committee attaches to the principle that both employers and trade unions should bargain in good faith, making every effort to come to an agreement" (See 139th Report of the Committee on Freedom of Association, Case No.725 (Japan), 1974, para.221 at 279; ILO, 1985, Digest, para.590).

In the most recent CFA Digest, the voluntary nature of negotiation between the parties is stressed, no doubt indicating the importance of freedom of choice (ILO Digest, paras.814817). Initially, the Committee also seemed reluctant to insist that a duty to bargain in good faith be imposed by legislation. In a case concerning collective bargaining in Alberta colleges, the CFA noted the government's assurance that even in the absence of a statutory duty "the bargaining environment was based upon mutual respect and shared decision-making" (214th Report of the Committee on Freedom of Association, Case No.1055 (Alberta), 1982, para.332 at 348).

However, later cases seem to treat the duty to bargain in good faith as a more stringent requirement which can and should be imposed by legislation. For example, in a case concerning Paraguay, the trade union complained of a delay in almost two years in renewing a collective agreement with the Bank of Brazil. The Bank's delaying tactics, including their refusal to discuss the matter with the trade union, were strongly criticised with reference to the principle of a duty to bargain in good faith. (See 236th Report of the Committee on Freedom of Association, Case No.1275 (Paraguay), 1984, para.444 at 475). The Committee issued similar statements in a case concerning Colombia, where the undertaking in question had refused to discuss a list of grievances submitted by the union, instead placing pressure upon employees to resign from the trade union constituted a breach of the duty to bargain in good faith. Indeed, the Committee recommended that immediate action be taken (236th 
Report of the Committee on Freedom of Association, Case No.1291 (Colombia), 1984, para. 686 at 695$)$.

More recently, the Committee emphasised the importance of a duty to bargain in two United Kingdom cases brought by the UK Trades Union Congress (TUC) (294th Report of the Committee on Freedom of Association, Case No. 1730 (United Kingdom), 1994, para.48). The Wilson and Palmer cases concerned workers who were denied a pay increase as a direct result of their refusal to give up the right to collective bargaining. Recent changes to UK industrial legislation meant that the employees in question had no recourse to a remedy for such action, which was short of dismissal, but would effectively deter a worker from becoming a trade union member. This action was found to be discriminatory and contrary to the obligation to bargain in good faith.

This conclusion was reiterated by the ILO Committee of Experts who, in their 1996 Report, asked the UK Government to further amend the legislation "so as to ensure the effective protection of workers from any action taken by the employer, or omission to act, which would result in penalizing workers for attempting to regulate their terms and conditions of employment through collective bargaining" (ILO, 1996, Report of the Committee of Experts on the Application of Conventions and Recommendations, pp.224-225).

This last case suggests that if employers are to enter into collective bargaining in good faith, they cannot offer employees incentives to enter into individual employment contracts. Moreover, it would seem that the ILO now advocates legislative reform where there is no other means of imposing such an obligation upon employers.

The imposition of such a duty to bargain in good faith would not require employers to reach agreement with trade union representatives, but would prevent an employer from using underhand tactics to undermine negotiations. Accordingly, the duty to bargain in good faith might be viewed as an ideal compromise between the active promotion of collective bargaining and the preservation of freedom of choice.

\section{Committee on Freedom of Association decisions relating to New Zealand legislation}

New Zealand is a member of the ILO, but has not ratified either Convention 87 or Convention 98. Nevertheless, the CFA considered itself entitled to assess New Zealand legislation with reference to the principles contained in the two Conventions, since:

By membership of the International Labour Organisation, each member State is bound to respect a certain number of principles including the principles of freedom of association which have become customary rules above the Conventions. (ILO, 1985, Digest, para.53; ILO, 1996, Digest, ch.1).

It should be noted that membership of the ILO and compliance with ILO standards remain voluntary (Haworth and Hughes, 1995: 159). New Zealand cannot be forced to retain its membership of the ILO, or to comply with its standards. Nevertheless, the persuasive weight 
of its recommendations should not be ignored. This is an organisation which has just celebrated its 75 th anniversary. It boasts membership of over 170 states and the labour standards which it promotes are the product of extensive argument between representatives of governments world-wide, as well as worker and employer representatives.

New Zealand was one of the first members of the ILO, but in all probability has never complied with ILO guidelines relating to freedom of association. The New Zealand system of compulsory conciliation and arbitration, dating from 1894, involved extensive state intervention in collective bargaining, beyond that contemplated by ILO principles. It may therefore seem ironic that recent legislation, which entirely demolished the system of industry-wide awards and registered collective agreements, is also seen as contravening international standards.

However, the Committee on Freedom of Association seems merely to have been caught in the struggle to promote both collective bargaining and freedom of choice. Given the need to reconcile these two conflicting elements of freedom of association, the Committee's criticism of the New Zealand Employment Contracts Act is not entirely out of character. Their decision is but one of many indications that official organs of the ILO are increasingly sceptical of the rhetoric surrounding "freedom of choice", where the result is that workers are deprived of the protection which collective bargaining provides (ILO Committee of Experts, 1994: 142-143).

\section{Freedom of choice relating to trade union membership: Case No.1334, 1986}

New Zealand legislation relating to the issue of trade union membership fluctuated. Initially, from 1894 onwards, parties could negotiate a "union membership clause", which could then be included in awards or agreements. There were two types of "union membership clause". The first was the "qualified preference clause" which required that union members should have preference for jobs. The second was the "unqualified preference clause" which required that adult workers covered by an award or an agreement should become union members within 14 days of taking a job. ${ }^{4}$

In 1936 the first Labour Government introduced compulsory union membership, so that a worker had to join a trade union, if employed in a job which was covered by a registered trade union.s Subsequent National Governments attempted to abolish the legal requirement of compulsion, but continued to allow the practice of including union membership clauses in agreements and awards. In 1976 and 1978, a National Government introduced ballots on the

$4 \quad$ Summarised in the New Zealand Government's Response to the NZCTU Complaint to the ILO 1994 , p. 18 , para. 36.

$5 \quad$ Although compulsory membership was subject to certain provisos. You did not have to join the union before you were eligible for employment and you did not have to join a trade union if you were in an occupation which was not covered by an unqualified preference clause. Public service unions were also voluntary. 
unqualified preference clause by all employees affected. To the government's great surprise and embarrassment, employees voted overwhelmingly for these clauses. The National Government subsequently outlawed union membership clauses altogether, in the Industrial Relations Amendment Act 1983 which came into force on 1 February 1984.

When Labour returned to office in 1984, the government attempted to promote union membership by a two-step approach. The relevant legislation provided for an initial 18 month period of compulsory union membership, after which time unions could hold national industry-wide ballots to determine the continuation of compulsory trade union membership, via a clause to be inserted in the relevant award or agreement. However, provision was made for the exception of conscientious objectors. A three-person tribunal (the Union Membership Exemption Tribunal) heard applications from people who wished to be exempt from union membership on grounds of conscience.

It was at this point in the union membership debate that the New Zealand Employers Federation (NZEF) called upon the ILO to intervene. ${ }^{6}$ The sceptical analyst might question the extent to which the NZEF was really concerned with workers' free choice. It was no doubt in the employers' interests to reduce the membership of trade unions and therefore their bargaining power. However, it was always unlikely that such a complaint could have been brought by the New Zealand Federation of Labour (FOL), which had for years relied upon the resources and political power guaranteed by virtually compulsory trade union membership in many private sector occupations.

The Labour Government claimed that these provisions were intended "to restore to employees a membership base which recognises a collective responsibility of workers to their organisation, and provides for their participation in a democratic ballot to determine further the basis of union membership" (Case No.1334, 1986, p.26, para.96). Nevertheless, the ILO Committee on Freedom of Association decided that the 18 month period of compulsory union membership was not in conformity with the principle that "workers should be able to form and join organisations of their own choosing" (Case No.1334, 1986, p.33, para.123). The CFA was also critical of the procedure the legislation prescribed for balloting, but considered that trade union determination of membership requirements via a ballot was not itself in conflict with the principle of freedom of association.

This result could have been anticipated, given the demarcation between trade union autonomy and government activity noted above (supra, pp.4-5). The CFA were obviously reluctant to allow government any influence over collective bargaining. The ILO defines the government's role in terms of facilitation of industrial organisations and collective bargaining, but

244th Report of the Committee on Freedom of Association, Case No.1334, New Zealand 1986. The first case brought to the attention of the CFA by the New Zealand Public Service Association (PSA). That complaint concerned the actions of the Muldoon National Government which introduced into Parliament draft legislation which would have authorised the Minister of State to deregister the PSA and confiscate its assets in respect of any strike which caused or was likely to cause serious loss or inconvenience. However, this legislation was withdrawn and the complaint abandoned. See 197th Report of the Committee on Freedom of Association, Case No.936, New Zealand 1979. 
will not permit interference. This is obviously a difficult distinction to maintain, but follows from the Committee's attempts to reconcile promotion of collective bargaining and individual freedom of choice.

\section{The Labour Relations Act 1988 - Case No.1385, 1988/1989}

The second complaint by the NZEF concerned the Labour Relations Act 1987 introduced by the Labour Government. This piece of legislation made substantial changes to the traditional system of conciliation and arbitration which had long been in violation of ILO standards, but was none the less viewed by the Committee on Freedom of Association as overly interventionist.

The 1984 legislation, earlier challenged by the NZEF, had introduced voluntary arbitration for the first time. This change was included in the new Labour Relations Act 1987, alongside the introduction of a limited right to strike. Moreover, the Labour Relations Act made provision for collective bargaining outside the traditional structure of awards and registered collective agreements, allowing for "enterprise bargaining" at workplaces (Labour Relations Act 1987, s.152). Groups of workers could enter into direct bargaining with an employer. This element of flexibility was a radical departure from the earlier industry-wide bargaining system.

The Act continued to allow unions registered under the Act to have enhanced representation and negotiation rights within the national awards structure, but significantly modified the conditions for registration. For example, the requirement that a union seeking registration represent a particular specified industry was abolished. "Mixed" trade unions became possible. A new precondition for registration was that the membership of the union making the application must be over a thousand; a requirement which would force smaller trade unions to combine organisations and increase bargaining power (Labour Relations Act 1987, s.6). A trade union could still be formed and represent workers outside the national award structure, even where its membership was below the thousand-mark. However, agreements concluded generally could not be registered or enforced under the Labour Relations Act. ${ }^{7}$

Trade union membership within certain industries was to be decided by industry-wide trade union ballot; but a statutory exception continued to be made for those who objected to trade union membership on grounds of conscience (Labour Relations Act 1987, ss.73-91). Union membership was a usual precondition of access to the Labour Court, to make a personal grievance claim, such as unjustified dismissal (Labour Relations Act 1987, ss.209-229). An obligation was placed upon registered trade unions to adequately represent their members in such claims. However, a claim could also be made by any person who had objected to union membership on grounds of conscience. Members of unregistered trade unions and independent contractors were expected to bring similar claims in the ordinary courts. 
The New Zealand Employers Federation, as could be expected, pointed to those features of the legislation which impinged upon individual choice. They complained that the registration system potentially obstructed workers' free choice as to which union should represent them (Case No.1385, 1988, pp.180-182, paras.521-526). The Labour Government, in defence of its actions, argued that their objective in enacting the legislation was to provide a means by which:

the trade union movement might form unions that were larger and more capable of providing the services and protections that workers need. The legislation provides the means for unions to move toward a more unified structure. (259th Report, Case No.1385, New Zealand, 1988, pp.182, para.529.)

In 1988 the CFA drew certain interim conclusions. It found that a system of registration of trade unions was not itself in violation of principles of freedom of association, but considered that a one thousand minimum membership requirement was liable to "deprive workers in bargaining units covering a limited number of workers of the right to form organisations capable of fully exercising their activities, contrary to principles of freedom of association" (Case No.1385, 1988, p.190, para.552). In addition, the Committee requested that the Labour Government supply supplementary information concerning the number of unregistered unions, the activities they carry out and remedies available to members of unregistered unions when personal grievances arise.

Following further information provided by the New Zealand Government, the Committee reached its final conclusion. The CFA reiterated its view that the one thousand minimum membership requirement was contrary to the principle of freedom of association (Case No 1385,1989 , pp.80-81, paras.279-280). Moreover, it went further and criticised the provision of incentives for registration, as these effectively hampered workers' ability to join unregistered trade unions. The Committee stated that:

the formation of other unions outside the registration system ... could be seriously hindered in so far as workers would be motivated to join only registered organisations since such organisations enjoy broader rights, and that the system thus indirectly brings into question the workers' right to establish and join organisations of their own choosing. (Case No.1385, 1989, p.81, para.282.)

Again respect for free choice of the individual seems to provide the foundation of the CFA's decision.

\section{The Case of the Employment Contracts Act 1991, Case No.1698, 1994}

In 1991, the newly elected National Government radically changed the legislative framework for New Zealand industrial relations. The Employment Contracts Act 1991 (ECA) sought to "promote an efficient labour market". The Preamble to the Act also expressly stated that a particular aim of the legislation was "to provide for freedom of association". This being the case, it is interesting that the Committee on Freedom of Association found fault with the statute 
Briefly, the ECA abolished the old system of union registration, as well as centralised, state-endorsed collective bargaining. Instead, the Act opened the way for employers and employees to "choose" either individual and collective employment contracts. Indeed, the ECA relies heavily on the rhetoric of "free choice", with respect to both employers and employees in the negotiation of employment contracts. Under the Act, employees and employers can authorise "bargaining agents" to conclude contracts on their behalf, but unions do not automatically constitute employees' bargaining agents. (See Employment Contracts Act 1991, s.11.)

In fact, it seems that union involvement in the collective bargaining process has been sharply curtailed. The New Zealand Council of Trade Unions (NZCTU), in their complaint to the IO, stated that the number of workers covered by a collective agreement has dropped by 45 percent since the 1989-1990 wage round. ${ }^{8}$ Moreover, union membership is now entirely voluntary and the system of "employment contracts" effectively precludes even balloted compulsory union membership agreements.

While the statute is "formally neutral" and does not prohibit collective bargaining, it effectively diminishes the capacity of representative associations to negotiate upon the members' behalf (Case No.1698, 1994, pp.235-237). Rights of access to workplaces have diminished, but perhaps more serious than this are the allegations of employers' tactical attempts to thwart the collective bargaining process.' For example, employers have offered superior terms to those employees willing to enter into an individual as opposed to a collective employment contract. Other tactics include onerous demands for proof of authorisation of bargaining agents, limitations upon trade union access to the workplace, employer domination of employee organisations and attempts to bargain directly with workers who have appointed a bargaining representative (Case No.1698, 1994, pp.212-215, paras. 689-695).

The Employment Contracts Act provides remedies for undue influence and discrimination on the grounds of union membership, but the NZCTU alleged that the Act and the courts have not provided sufficient protection for workers (Case No.1698, 1994, pp.229-232). They have questioned the reality of an employee's ability to choose to join a collective employment contract (CEC) when an employer is only prepared to countenance an individual employment contract (IEC). Economic power is generally on the side of the employer and there is little scope for recognising imbalance of bargaining power in the law of contract. In New Zealand,

Case No. 1698, 1994, p. 210 . Even the Government concedes a drop from 65 percent union coverage to 55 percent. Also, the number of individual employment contracts rose from 28 percent of all employment contracts in May 1991 to 52 percent in August 1992. See p.218, para.701. Raymond Harbridge of Victoria University of Wellington claims that collective contracts are unlikely to cover more than 22 percent of the workforce. Committee on the Inquiry into the Effects of the Employment Contracts Act on the New Zealand Labour Market 1993. 
there is certainly no common law remedy to redress the general imbalance of bargaining power between employer and employee. ${ }^{10}$

Strikes may be regarded as a vital counter to imbalances of power typically existing when an employer bargains with an employee, but the Employment Contracts Act makes limited provision for strike action. For example, strikes will be legal where they relate to negotiation of a collective employment contract (CEC) where one is not already in force, but s.63 prevents a strike in pursuit of an industry-wide or multi-employer agreement (Employment Contracts Act 1991, ss.63 and 64).

The National Government asserts that the Act is one amongst a series of deregulatory policies which have promoted economic growth and employment in New Zealand. ${ }^{11}$ The Majority Report on the effects of the Employment Contracts Act, undertaken by and endorsed by the government, considered that, overall, real wages had increased by two and a half percent since 1991. However, they had to concede that in some workplaces workers "have either lost pay or are working for similar pay, but for longer hours" (Report of the Labour Committee, 1993: 11-12).

The Minority Report, released simultaneously by several members of the same Committee of Inquiry was more critical. They relied on evidence which the majority had dismissed as "anecdotal" to draw their conclusion that there emerged "a pattern of cuts in wages and conditions often associated with obstructive bargaining by employers" (Report of the Minority of the Labour Select Committee, 1993: 15). Moreover, they found that no clear evidence of macroeconomic effects was presented to the Committee, but noted NZCTU submissions that 40,000 full-time jobs had been lost since the National Government came to power.

The Committee on Freedom of Association did not comment on New Zealand's supposed economic recovery, but focused instead on the principle of "freedom of association". The Employment Contracts Act was intended to provide parties to employment contracts with "freedom of choice"; but it was another aspect of freedom of association, namely the promotion of collective bargaining, which was lacking.

The Committee's request that "the government ... take appropriate steps to ensure that legislation encourages and promotes the development and utilisation of machinery for voluntary negotiation between employers or employers' organisations and workers' organisations" (Case No.1698, 1994, p.236, para.741) is strongly reminiscent of Article 4 of Convention 98, upon which the NZCTU relied in making their complaint. In addition, the Committee expressed concern "that the emphasis on individual responsibility for bargaining

10 See, for example, judgment of Palmer J. in Canterbury Hotel etc. IOUW v Lincoln College.

11 Statement by New Zealand Permanent Representative, A.M. Bisley to the ILO Governing Body, 259th Sessions; Speech by the New Zealand Minister of Labour, Hon. Doug Kidd to the Plenary Session of the International Labour Organisation, 8 June 1994; New Zealand Government's Response to the NZCTU Complaint to the ILO 1994. 
in the Act ... can be detrimental to collective bargaining" (Case No.1698, 1994, p.230, para. 728).

However, these were merely the Committee's interim conclusions. Subsequent to the publication of the CFA's initial decision, an ILO Direct Contacts Mission visited New Zealand. In November 1994, the CFA produced a second report, which incorporated the conclusions reached by the Mission.

The report of the Direct Contacts Mission, carried out by Alan Gladstone, outlined the evidence for and against the NZCTU complaint. In style, it was generally neutral, and uncritically set out both sides of the argument. Certain comments could be constructed as supporting the government's and employer's views, ${ }^{12}$ and he did review at length recent decisions of the New Zealand courts, which place restrictions on employer's attempts to bypass authorised bargaining representatives. ${ }^{13} \mathrm{Mr}$ Gladstone recognised that there remained "a limited number of issues which could be reflected in legislative change"; he merely suggested that these might not be irremediable. Nevertheless, his views are not to be taken as authoritative, as he himself stressed at the beginning of his report:

the report does not formulate conclusions or recommendations on the various issues involved in Case No.1698; that is the sole responsibility of the Committee on Freedom of Association, whose conclusions are not, and should not be, prejudged.

By contrast, the CFA took a firmer position. Firstly, the Committee stated that it was not interested in claims that the Act has led to an improvement in the economic situation of New Zealand. Economic efficiency was not the issue. Rather, any economic management should comply with the basic principles of freedom of association (295th Report of the Committee on Freedom of Association, Case No.1698, 1994, pp.78-78, paras.237-238). This approach dates from the Declaration of Philadelphia, where ILO delegates agreed that social justice must take priority over economic demands. ${ }^{14}$ However, 40 years later, such a statement seems courageous and surprising, given current emphasis on economic justifications for policy-making, especially in the sphere of "human resources".

12 See, for example, Annex to the 295th Report of the Committee on Freedom of Association on Case No. 1698, Report of the Direct Contacts Mission to New Zealand by Mr Alan Gladstone, Representative of the Director-General of the International Labour Office 1994, p.92 where he notes the inevitability of a decline in collective bargaining under the Employment Contracts Act and pp.93-95 where he states that he is looking for patterns detrimental to collective bargaining that the courts will be unable to correct, rather than the cost of litigation for employees.

13 Annex to the 295th Report of the Committee on Freedom of Association, Case No. 1698, 1994, op.cit., pp.100-103.

14 Article 2(c) of the Declaration of Philadelphia 1944 states that "all national and international policies and measures, in particular those of an economic and financial character, should be judged in this light and accepted only in so far as they may be held to promote and not hinder the achievement of this fundamental objective" (i.e. social justice). 
Second, the CFA took note of recent developments in New Zealand case law which suggest that courts will take action to protect workers from certain abuses, such as an employer's attempt to exercise undue influence or bypass a duly appointed bargaining agent. However, the Committee stated that "it is not clear whether and to what extent the reasoning of the courts applies to other issues" raised by the NZCTU complaint, such as employer interference and domination. Moreover, "from a more general perspective, questions also arise concerning the existence and extent of a duty to bargain collectively" (295th Report of the Committee on Freedom of Association, Case No.1698, 1994, pp.80-83, paras.242-249).

In addition, the Committee on Freedom of Association referred to circumstances in which "workers are in fact able to exercise the freedom of choice" (295th Report of the Committee on Freedom of Association, Case No.1698, 1994, p.83, para.253). This suggests that the Committee is not abandoning recognition of "freedom of choice" as a key element of freedom of association, but merely being realistic about the context in which choices can freely be made. Given the superior power of employers in an individual bargaining situation, the CFA doubted that employees would have the choice to engage in collective bargaining, until collective bargaining was actively promoted by the government. (See 295th Report of the Committee on Freedom of Association, Case No.1698, 1994, p.84, paras.255-258.)

The CFA rejected the government's view that problems brought to the attention of the Direct Contacts Mission were merely "anecdotal" and insufficiently widespread to be of concern. Instead, the Committee considered that "a significant number of collective bargaining problems have arisen and continue to arise in practice" (295th Report of the Committee on Freedom of Association, Case No.1698, 1994, p.83, para.252). While workers' organisations may continue to be effective in certain industries and undertakings, the CFA expressed concern that problems may arise in small to medium enterprises where workers are relatively isolated. The lack of a right to strike to promote industry-wide bargaining in such situations left those workers without any effective bargaining power. (See 295th Report of the Committee on Freedom of Association, Case No.1698, 1994, pp.85-86; paras.253-261.)

The second CFA report ended by recommending that the government take active steps to promote and encourage collective bargaining (295th Report of the Committee on Freedom of Association, Case No.1698, 1994, p.84, para.255). It may be difficult to judge what measures should be taken, given ILO condemnation of the past attempts by the New Zealand Government to do exactly this. However, the CFA suggested that the solution might be reached by a process of tripartite negotiation. The Committee recommended that government "initiate and pursue tripartite discussions as a process of ensuring that the provisions of the Employment Contracts Act are fully consistent with those principles" (295th Report of the Committee on Freedom of Association, Case No.1698, 1994, para.261(b)). 
This is an option which the Minister of Labour, Mr Doug Kidd, emphatically rejected. ${ }^{15}$ Indeed, the National Government has refused to initiate any legislative changes in response to the report. Instead, they launched what would seem to amount to a propaganda campaign. The second CFA report was said to be "radically different from its interim report in March", and the government claimed that "the Committee has stepped right back from supporting the NZCTU's complaint". ${ }^{16}$ It seems unlikely that any significant action will be taken by the present governmenit to respond to the CFA's criticisms. ${ }^{17}$

\section{Recent New Zealand case law}

The temptation is to turn to the New Zealand courts; to rely upon the judiciary to fill the glaring lacunas in the Act and to prevent injustice being done. It is arguable that the courts could, for example, when interpreting provisions contained in Part II of the Employment Contracts Act, develop an implicit duty to bargain in good faith. However, although the judiciary have taken certain steps in this direction, they seem reluctant to recognise such a duty in its entirety.

In the first CFA report on the Employment Contracts Act 1991, the Committee noted that the statute placed no obligation upon an employer to bargain in good faith with any representative appointed by the employee (292nd Report of the Committee on Freedom of Association, Case No.1698, 1994, p.208, at p.211, paras.684-686). In the Committee's final report, the CFA noted that new labour legislation often required "a period of testing and judicial interpretation before it can be applied with certainty". In this respect, the Committee observed that the evolution of case law had clarified a number of issues and requested that the New Zealand Government "keep it informed of the results of those proceedings and other judicial proceedings of significance" (295th Report of the Committee on Freedom of Association, Case No. 1698,1994, p.83, para.250).

15 On Radio New Zealand "Morning Report", 17 November 1994, Mr Kidd commented "that's actually a wonderful vintage piece of ILO you see, the ILO can't actually send out . . . a page without somewhere getting the phrase collective bargaining and the other phrase, tripartite discussions, on it, otherwise it's not the ILO . . . there's in fact nothing to be done."

16 Office of the Minister of Labour Media Release, 16 November 1994. In the New Zealand Employers' Federation, Public Statement, 17 November 1994, the NZEF responded in a similar vein, expressing its pleasure that the ILO had recognised the "underlying philosophy" of the Employment Contracts Act and had come to realise that its concerns were largely unwarranted. This approach was criticised by the New Zealand Council of Trade Unions in its Media Release of 17 November 1994. moreover, the General Secretary of the International Confederation of Free Trade Unions (ICFTU) and the spokesperson for the ILO Employers' Group condemned the New Zealand government's response.

17 The Governing Body noted this failure. See the ILO, Governing Body, Minutes of the 261st Session, GB 261/PV (Rev.), Geneva, November 1994, pp.V/2-V/3. However, the ILO has failed to take any further action. 
At the time of the CFA's final report, a number of cases had been decided allowing trade unions greater access to the workplace and placing restrictions upon employers' attempts to bypass authorised bargaining representatives. There have been further developments in both these areas.

For example, the Court of Appeal's judgment in Foodstuffs (Auckland) Ltd v National Distribution Union Inc has established the basic conditions for access to the workplace. Employees are entitled to be paid when their representative meets with them to discuss new contract negotiations. Group meetings are to be permitted, in so far as this was "reasonable", and a fair balance has to be struck between the employer's interests and those of the employee's and their representatives.

There have also been a number of cases concerning the extent to which direct communications between employers and their employees should be limited in accordance with s.12 of the Employment Contracts Act, which relates to recognition of authorised bargaining representatives. The earlier decision of the Court of Appeal in Eketone v Alliance Textiles established that "to go behind the union's back does not seem to be consistent with recognising its authority". However, subsequent cases seem to have fallen short of this far-reaching principle, despite the efforts of Goddard CJ.

In Ford v Capital Trusts Ltd, Goddard CJ granted an interim injunction where a memorandum was generally critical of the trade union's handling of the dispute, claiming a campaign of misinformation. Later in September of the same year, Colgan J refused an interim injunction in Couling $v$ Carter Holt Harvey, on the basis that communications about negotiations did not necessarily amount to negotiations and that s.12(2) would not amount to a blanket ban on such communications. Goddard CJ's response in New Zealand Air Line Pilots Association v Airways Corporation of New Zealand Limited was that, although it was a question of fact whether a particular communication amounted to a negotiation, it was possible for particular communications that do not amount to negotiations to involve a failure to recognise the authority to negotiate or to respect the employees' choice under s.10 ECA. Goddard CJ added that a representative's request to an employer not to communicate directly with the employees represented is an indication that the representative perceives that such a communication is likely to interfere with its ability to communicate efficiently. In communicating directly with represented employees, the employer takes the risk that the representative's perception will be held to be reasonable and the employer responsible for interference.

Nevertheless, the decision of the Court of Appeal in Capital Coast Health Ltd v New Zealand Medical Laboratory Workers Union Inc suggests that employers' communications will be treated more leniently than Goddard CJ indicated. The members of the Court viewed their task as a practical one, namely striking a balance between an employer's right to freedom of speech (protected under the Bill of Rights) and employees' rights under the Employment Contracts Act. Indeed, it could be said that once again the courts were faced with the conflict between the employer's individual rights and the protection of employees' collective interests; a dichotomy familiar to labour law. In Capital Coast, the employer had written to employees advising them of the consequences of their strike action and the arrangements which the employer intended to make to minimise the cost of a strike. The Court admitted that there 
was a fine "dividing line between informing and warning (which are permissible) and threatening if a negotiating position were abandoned (which is not permissible)". In that case, the employer's communication fell on the right side of the dividing line and was legitimate.

In addition to cases in these discrete areas, it has also been established that employers may be in breach of the Act where they deviate from agreed negotiation procedures. In Davson $v$ Tasman Pulp and Paper, a lockout was found to be unlawful because the employees did not receive a copy of the proposed collective employment contract until after the lockout commenced. It was claimed that this conduct breached an agreement as to how negotiations would proceed, and accordingly an interim injunction was granted. Davson appears to endorse a kind of good faith approach, but this is clearly only relevant where bargaining is in process and the appropriate procedures agreed upon (cf. Kelly, G.M., 1995: 352). Ultimately, the New Zealand courts stop short of recognising a duty to bargain in good faith. They have long acknowledged that contractual relationships involve a common law obligation of trust and confidence, but are unlikely to impose a requirement that the parties make every effort to come to a collective agreement. Moreover, the New Zealand courts seem unlikely to place any restriction placed upon the incentives which an employer may offer to persuade employees to sign individual employment contracts (cf. supra, pp.6-7). The cases mentioned above fail to recognise the duty to bargain in good faith, as developed by the ILO Committee on Freedom of Association.

It is clear that the judiciary consider themselves constrained by the literal wording of the Employment Contracts Act. They deliberately do not attempt to incorporate international labour standards, or indeed the criticisms made by the CFA. In Ivamy v New Zealand Fire Service, Goddard CJ commented that the Court did not have regard to freedom of association Conventions 87 and 98 for the purpose of interpreting legislative intention at the time of the enactment of the Employment Contracts Act, as New Zealand has not ratified those conventions. He does not adopt the view that as a member of the ILO, New Zealand is bound to abide by the principle of freedom of association (cf. supra, pp.7-8). Similarly, on appeal, the Court of Appeal commented that this case was solely a case governed by an existing Act of Parliament and the Court would not be concerned with the desirability or otherwise of what Parliament had laid down. This case was not to be a general inquiry into the role of trade unions and the law that is appropriate in that connection

In the absence of any standard of conduct written into the Employment Contracts Act it seems unlikely that the New Zealand courts will take any further steps to impose any duty to bargain in good faith upon participants in collective bargaining. If New Zealand is to comply with the recommendations made by the ILO it seems that legislative action must be taken.

\section{Conclusion}

Over the past decade, the ILO Committee on Freedom of Association has considered numerous cases relating to New Zealand industrial relations. To some extent its findings have been contradictory, stemming from a long-standing contradiction implicit in the very nature of "freedom of association". The CFA has been faced with the task of reconciling protection 
of freedom of choice with the need to protect workers' collective action in defence of their interests.

The Committee's decision on the New Zealand Employment Contracts Act serves as an important reminder that the term "freedom of association" does not only conjure up the spectre of individual liberty. Were that so, we would be talking about "freedom" alone. Instead, the crucial reference is to "association", or collective action. This places an important caveat on the protection of "freedom of choice", requiring that individual freedom be balanced against the collective protection of workers' interests.

Accordingly, it seems desirable to investigate the ways in which New Zealand might modify its industrial relations system to promote collective bargaining, without government intervention unduly restricting freedom of choice. The answer might lie in the imposition of a duty to bargain in good faith, a principle developed by the Committee on Freedom of Association over a period of years.

Little action has been taken by the present government, but recent decisions in the Employment Court and the Court of Appeal indicate an appreciation of problems associated with a lack of commitment to collective bargaining, such as lack of trade union access to the workplace and the bypassing of bargaining representatives. Nevertheless, without a statutory provision to this effect, the judiciary are reluctant to impose a duty upon trade unions and employers to bargain in good faith as advocated by the CFA. It is suggested that legislative reform is vital, if New Zealand is to comply with ILO standards.

\section{References}

Ben-Israel, Ruth (1989), International Labour Standards: The Case of Freedom to Strike, Deventer, Kluwer.

Collins, H. (1986), Market Power, Bureaucratic Power, and the Contract of Employment, Industrial Law Journal, 15: 1-14.

Creighton, B. (1993), Freedom of Association. In Blanpain, R. and Engels, C. (eds.) Comparative Labour Law and Industrial Relations in Industrialized Market Economies, 5th ed., Deventer, Kluwer.

Deeks, J. and Boxall, P. (1989), Labour Relations in New Zealand, Auckland, Longman Paul.

Director-General of the ILO (1994), Defending Values, Promoting Change: Social Justice in a Global Economy: An ILO Agenda, Geneva, International Labour Office.

Haworth, N. and Hughes, S. (1995), Under Scrutiny: The ECA, the ILO and the NZCTU Complaint, New Zealand Journal of Industrial Relations, 20(2): 143-161. 
Hodges-Aeberhard, J. and de Dios, O. (1987), Principles of the Committee on Freedom of Association Concerning Strikes, International Labour Review, 126: 543-563.

Hyman, R. (1989), Strikes, 4th ed. Basingstoke, Macmillan.

International Labour Office (ILO) (1931), The International Labour Organisation: The First Decade, London, Allen and Unwin.

ILO (1975), Report of the Fact-Finding and Conciliation Commission on the Trade Union Situation in Chile, Geneva, International Labour Office.

ILO (1979), 197th Report of the Committee on Freedom of Association, Case No.936 (New Zealand), Geneva, International Labour Office.

ILO Committee of Experts (1983), General Survey by the Committee of Experts on the Application of Conventions and Recommendations concerning Freedom of Association, Geneva, International Labour Office.

ILO (1985), Freedom of Association: Digest of Decisions and Principles of the Freedom of Association Committee of the Governing Body of the ILO, 3rd ed., Geneva, International Labour Office.

ILO (1986), 244th Report of the Committee on Freedom of Association, Case No.1334 (New Zealand), Geneva, International Labour Office.

ILO (1988), 259th Report of the Committee on Freedom of Association, Case No. 1385 (New Zealand), Geneva, International Labour Office.

ILO (1989), 265th Report of the Committee on Freedom of Association, Case No.1385 (New Zealand), Geneva, International Labour Office.

ILO Committee of Experts (1994), Freedom of Association and Collective Bargaining, Geneva, International Labour Office.

ILO (1994), 292nd Report of the Committee on Freedom of Association, Case No. 1698 (New Zealand), Geneva, International Labour Office.

ILO (1994), 295th Report of the Committee on Freedom of Association, Case No.1698 (New Zealand), Geneva, International Labour Office.

ILO (1994), Annex to the Second Report of the Committee on Freedom of Association on Case No.1698, Report of the Direct Contacts Mission to New Zealand by Mr Alan Gladstone, Representative of the Director-General of the International Labour Office, Geneva, International Labour Office. 
ILO (1996), Freedom of Association: Digest of Decisions and Principles of the Freedom of Association Committee of the Governing Body of the ILO, 4th ed., Geneva, International Labour Office.

ILO (1996), Report of the Committee of Experts on the Application of Conventions and Recommendations, International Labour Office, Geneva.

Jenks, C.W. (1957), The International Protection of Trade Union Freedoms, London, Stevens and Sons.

Kahn-Freund, O., Davies, P. and Freedland, M. (1983), Labour and the Law, 3rd ed., London, Stevens and Sons.

Kelly, G.M. (1995), Structural Change in New Zealand: Some Implications for the Labour Market Regime, International Labour Review, 134(3): 333-359.

Leader, S. (1992), Freedom of Association: A Study in Labour Law and Political Theory, New Haven, Yale University Press.

Mill, J.S. (1962), Utilitarianism, Glasgow, Fontana Press.

Nolan, D.R. (1991), RIP: Compulsory Labour Arbitration in New Zealand 1894-1984, Comparative Labor Law Journal, 12: 411-457.

Pouyat, A.J. (1982), The ILO's Freedom of Association Machinery: A Summing Up, International Labour Review, 121: 287-302.

Report of the Labour Committee on the Inquiry Into the Effects of the Employment Contracts Act 1991 on the New Zealand Labour Market (1993).

Report of the Minority of the Labour Select Committee on the Inquiry Into the Effects of the Employment Contracts Act on the New Zealand Labour Market (1993).

Servais, J. (1984), ILO Standards on Freedom of Association and Their Implementation, International Labour Review, 123: 765-781.

von Prondzynski, F. (1987), Freedom of Association and Industrial Relations: A Comparative Study, London, Mansell.

Lord Wedderburn (1994), Labour Law and the Individual in Post-Industrial Societies. In Lord Wedderburn, Rood, M., Lyon-Caen, G., Daubler, P. and van der Heijen, P., Labour Law in the Post-Industrial Era, Aldershot, Dartsmouth. 


\section{Cases}

Canterbury Hotel etc IOUW v Lincoln College [1988] NZELC 96, 232.

Capital Coast Health Ltd v New Zealand Medical Laboratory Workers Union Inc [1996] 1 NZLR 7.

Couling v Carter Holt Harvey [1995] 4 NZELC 98, 363.

Davson v Tasman Pulp and Paper [1995] 4 NZELC 98, 315.

Eketone v Alliance Textiles [1993] 2 ERNZ 783.

Foodstuffs (Auckland) Ltd v National Distribution Union Inc [1995] 2 NZLR 280.

Ford v Capital Trusts Ltd [1995] 2 ERNZ 47.

Gustafsson v Sweden, Application No.15573/89, European Commission of Human Rights: Decisions and Reports 77 - A, Strasbourg May 1994, Vol. V(II) Human Rights Digest (March - April 1994).

Ivamy v New Zealand Fire Service [1985] 1 ERNZ 724.

New Zealand Airline Pilots Association v Airways Corporation of New Zealand Limited, (WEC 72/95; Employment Court judgment given 14 November 1995).

New Zealand Fire Service v Ivamy (CA 145/95; Court of Appeal judgment given 20 October 1995).

Sigurjonsson v Iceland [1993] 16 EHRR 462.

Young, James and Webster v UK, Judgment of 13 August 1981, Series A., Vol. 44 4EHRR 38 [1982]. 